Bulatović, Srđan

Aleksić, Vujadin

Milović, Ljubica

Zečević, Bojana

http://dx.doi.org/10.21278/brod72301

\title{
AN ANALYSIS OF IMPACT TESTING OF HIGH STRENGTH LOW- ALLOY STEELS USED IN SHIP CONSTRUCTION
}

UDC 621.791.053:669.018:620.178.2

Original scientific paper

\begin{abstract}
Summary
Brittle damages have been examined widely since welding became common practice when it comes to carrying out robust structures. Welded structure of the ship hull has to be continuous. Brittle damages that occur on hull structures have always been examined thoroughly. Cracks are most commonly initiated at locations where stress concentrators exist. These concentrators can originate due to flaws that occur during the design phase or due to mistakes that occur during the assembly of the structure. When it comes to failures and damages that occur at ship structures, it has been noticed that damages due to brittleness practically always happen at low temperatures.

Impact test analysis is significant due to the fact that it replicates the ductile to brittle transition of steel in practically identical range of temperatures for all ship structures. Impact of ductile-brittle transition temperature is an important factor especially because there have been many ship failures and damages in history.

In ship structures made of welded joints of high strength low-alloy (HSLA) steels with their segments (parent metal, weld metal and heat-affected-zone), the toughness test determines the tendency of steel to brittle fracture, respectively the tendency to increase brittleness during exploitation. Parameters obtained by testing the properties of plasticity are the fundamental for the composition of ship structures with the aim of realize strengths under tested load.

The test results of high strength low-alloy steel toughness assessment at different test temperatures show that temperature significantly affects the impact toughness of steels and their alloys.
\end{abstract}

Key words: $\quad$ impact toughness; ship construction; high strength low-alloy steel; transition temperature

\section{Introduction}

One of main difficulties is to select the proper material out of many that are available. There are many parameters that affect the final decision. A material has to be selected 
primarily taking into account the characteristics demanded under exploitation conditions. It is rarely that a material owns the ideal combination of characteristics. Additionally, it is practically necessary to implement the regulations that refer to materials being used for hull making from widely recognized societies such as Lloyd's Register (LR), American Bureau of Shipping (ABS), Croatian Register of Shipping (CRS) and Det Norske Veritas (DNV) [1].

This paper primarily focuses on high strength low-alloy (HSLA) steels, which are most commonly being used for military ship structures. Due to their price and level of production technology, in addition to low carbon content (from 0.1 to $0.3 \%$ ), they also have low content of sulfur, phosphorus and other impurities, and are also characterized by increased purity in relation to gases and non-metallic inclusions. It is important to mention that the total content of all alloying elements does not exceed 5\%. The basic alloying elements that are added to low-alloy steels of high strength are: chromium, manganese, silicon, nickel, molybdenum and vanadium. Depending on the type of steel, the influence of alloying elements is determined by their effect on the ferrite reinforcement, the amount and dispersion of the carbide phase, hardenability and other factors. A very satisfactory level of plasticity and toughness is achieved by hardening and tempering, after appropriate heat treatment. In general, a significant influence on the properties of alloy steels (also applies to high strength low-alloy steels) has a chemical composition, whereas it can be said that other influencing factors on the properties of steels are directly related or are a consequence of the chemical composition.

HSLA and micro-alloyed steels are generally being used for producing of ship and offshore structures [2]. The most significant component that influences steel selection is the suitable strength-to-weight proportion of HSLA steels compared with regular low-carbon steels. Ship structures are most commonly being produced by welding. For this reason high strength low-alloy (HSLA) steels, besides high strength as the main properties, should also have exceptional plasticity, adequate toughness and high resistance to brittle damage, as well as adequate workability and good welding performance [3].

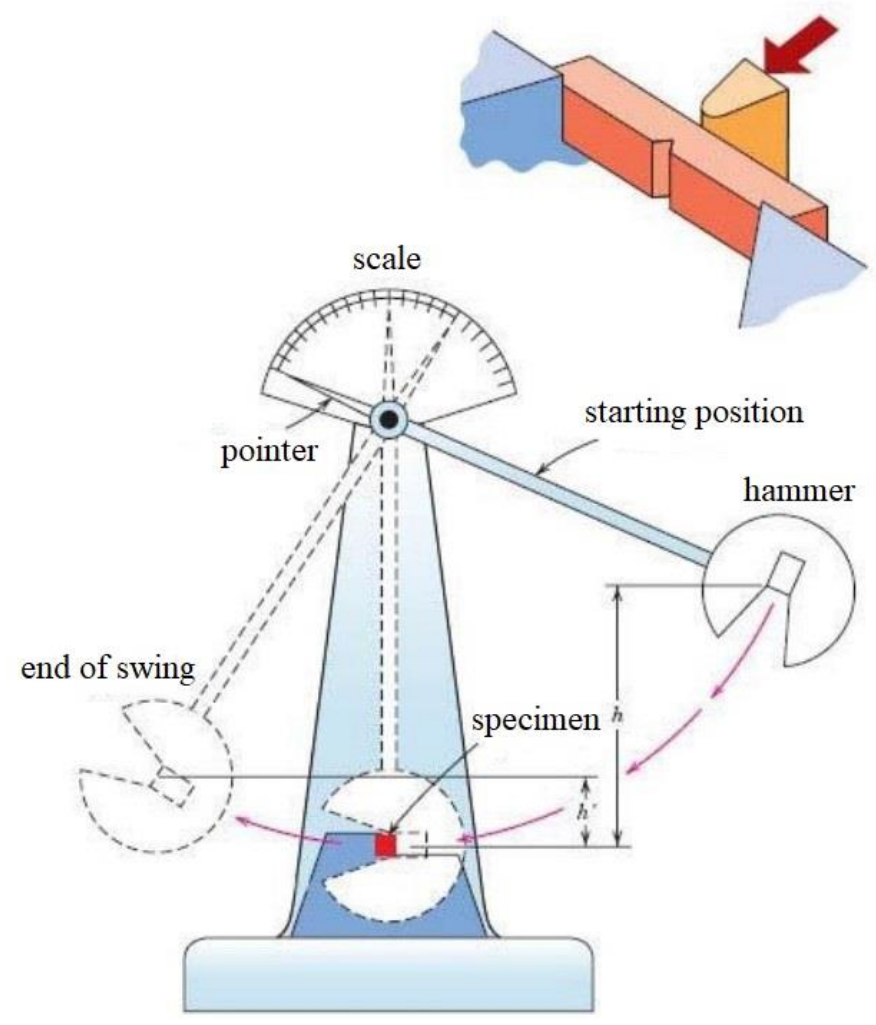

Fig. 1 Charpy pendulum impact test machine 
The ability of forming is an additional important metal characteristic, and for steels with high strength, the weldability is of special implication. As the requirements for safe use are higher, the material test of ductility properties and toughness parameters is determined, along with fracture toughness tests. In this test, the specified parameters are tested for three joint parts of welded joint, parent metal (PM), weld metal (WM) and the heat-affected-zone (HAZ). Requirement for safety of hull construction of ship, produced of steel with high strength has significance because of the repercussions of eventual fracture [4].

Brittle fracture tendency and accordingly the brittleness increase during ship exploitation can be determined by impact tests of the specimen with a notch in the parent metal, weld metal, and heat affected zone [5]. Impact tests (Fig. 1) are accomplished for determining the impact total energy, which is divided into two energies, crack initiation and crack propagation energy.

The test results of high strength low-alloy steel toughness assessment at different test temperatures show that temperature significantly affects the impact toughness of steels and their alloys. At higher temperatures the impact energy on fracture is high (the material shows the properties of plasticity) while at lower temperatures the impact energy is small (the material is brittle). Relation of impact toughness on temperature in the presence of ductile and brittle fracture is shown in Fig. 2.

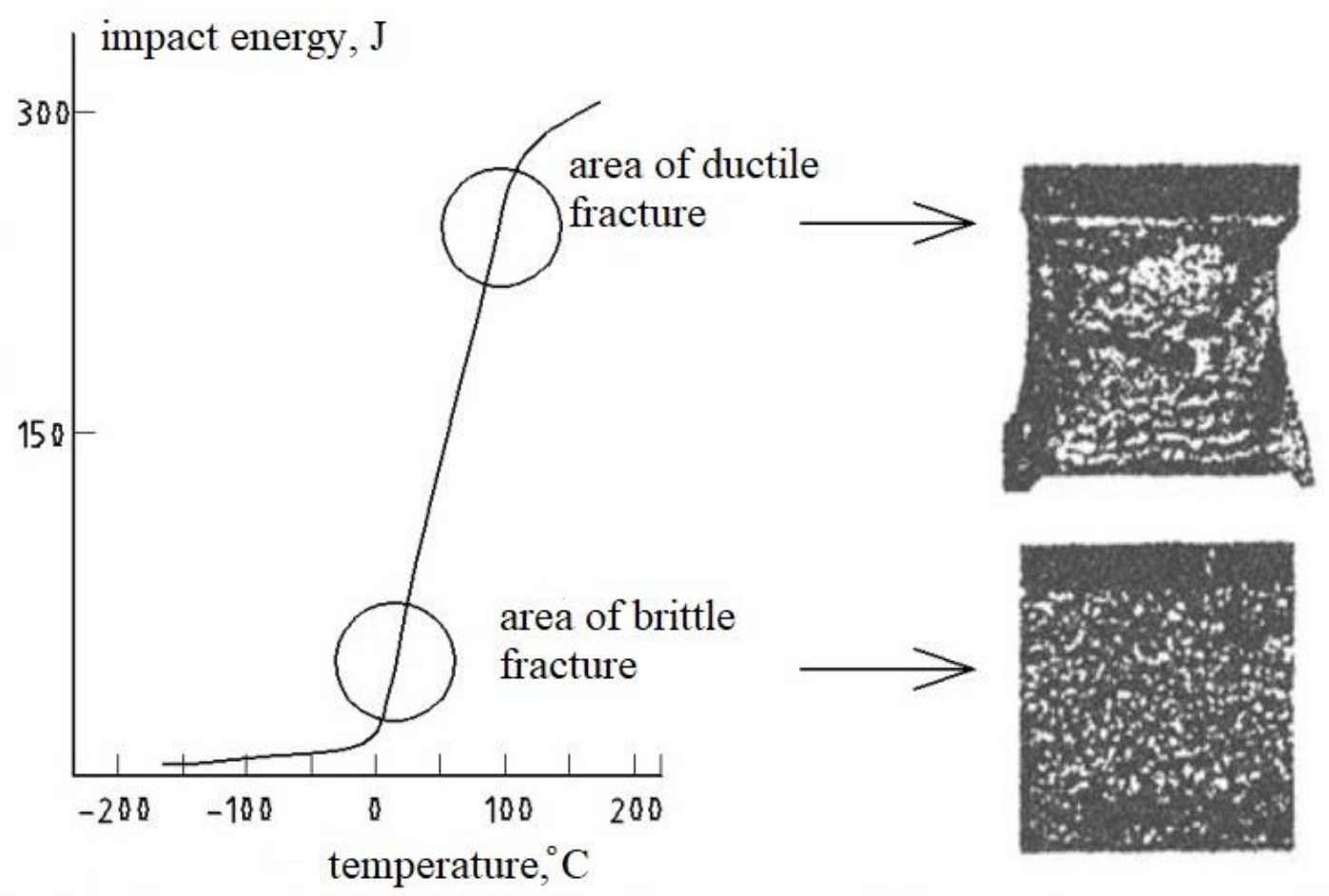

Fig. 2 Relationship between impact energy and temperature with ductile and brittle fracture surface for lowcarbon steel at $-25{ }^{\circ} \mathrm{C}[6]$

The transition temperature is an important factor for hull structural steels. It has been observed that with a drop in temperature, many metals show the property of a sharp drop in toughness, so the temperature at which the material changes from ductile to brittle fracture is called the ductile-brittle transition temperature. It is defined as the inflection point of the total impact energy-temperature curve [4, 7] and depends on a number of factors such as chemical composition, microstructure, metal grain size, surface roughness, specimen shape and notch depth. In general, the transition temperature from ductile to brittle fracture is particularly dangerous and characteristic of steels with BCC (body centred cubic) structure. Some other 
steels like those with FCC (face centred cubic) structure and high-strength and ultra-high strength steels do not show such a sharp drop in toughness by lowering the temperature.

The best example of the impact of the transition temperature is the failure of Liberty ships manufactured during World War II, Fig. 3. All ships were constructed of low carbon steels, which showed good plasticity properties in tensile testing. At the moment when the ships were anchored in the port, cracks appeared in a quarter of the ships, while some ships broke in two. The examination concluded that the accident occurred due to the stress concentration caused by the openings on the deck of the ships and the proximity of the transition temperature of steel and the ambient temperature in the port (high transition temperature in brittle fracture).

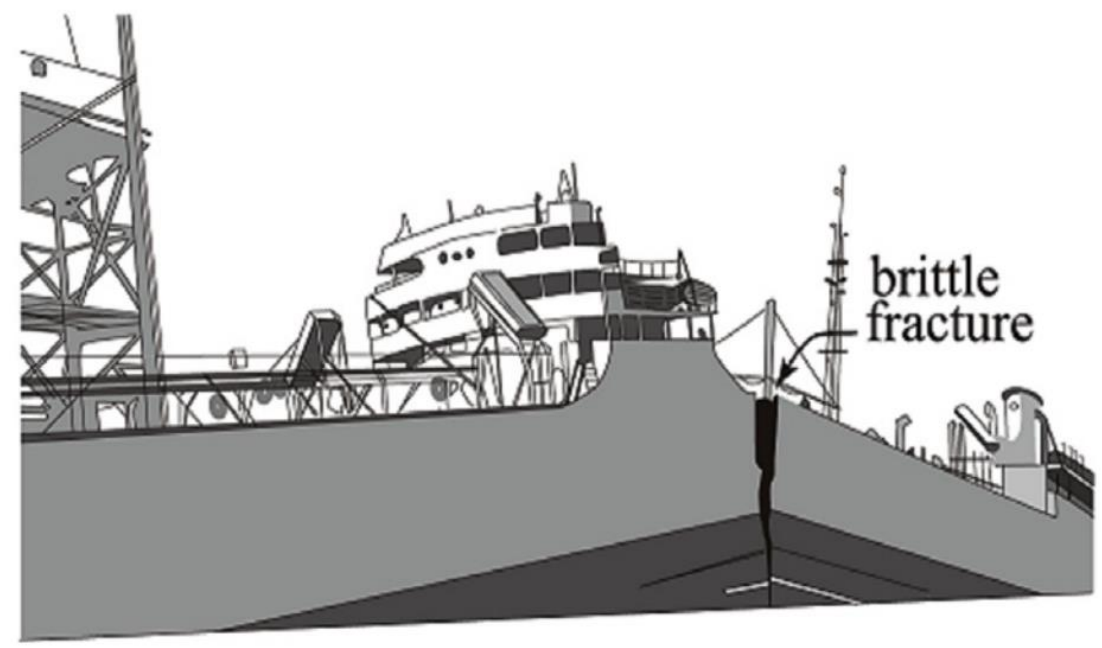

Fig. 3 Brittle fracture of "Liberty ships" [8]

\section{Impact toughness of HSLA steel}

The material applied in the current laboratory test was welded joint of high strength low-alloy steel (HSLA) Nionikral-70 (NN-70), applicable for ship constructions. As a contribution to a joint effort of the Military Technical Institute in Belgrade-Serbia (VTI) and the ironworks factory Jesenice from Jesenice-Slovenia, in the early 1990s, steel was produced. Steel is being made within the electric furnace and afterwards cast in plates, which are subsequently being rolled in order to form slabs and, finally, sheets. It belongs to the group of fine-grained steels due to many of its characteristics. Hardening is practically the combination of regular heat treatment (quenching and tempering) and grain refinement carried out in accordance with chemical composition of the material and including microalloying and adequate deposition $[9,10]$. It is important to note that grain boundary strengthening mechanism (grain refinement) influences most effectively to lower the transition temperature. The chemical composition of NN-70 is given in Table 1 .

Table 1 Chemical composition of NN-70 (\% wt)

\begin{tabular}{|c|c|c|c|c|c|c|c|}
\hline $\mathrm{C}$ & $\mathrm{Si}$ & $\mathrm{Mn}$ & $\mathrm{P}$ & $\mathrm{S}$ & $\mathrm{Cr}$ & $\mathrm{Ni}$ & $\mathrm{Mo}$ \\
\hline 0.106 & 0.209 & 0.220 & 0.005 & 0.0172 & 1.2575 & 2.361 & 0.305 \\
\hline \multicolumn{7}{|c|}{} \\
\hline $\mathrm{V}$ & $\mathrm{Al}$ & $\mathrm{As}$ & $\mathrm{Sn}$ & $\mathrm{Cu}$ & $\mathrm{Ti}$ & $\mathrm{Nb}$ & $\mathrm{Ca}$ \\
\hline 0.052 & 0.007 & 0.017 & 0.014 & 0.246 & 0.002 & 0.007 & 0.0003 \\
\hline \multicolumn{7}{|c|}{} \\
\hline $\mathrm{B}$ & $\mathrm{Pb}$ & $\mathrm{W}$ & $\mathrm{Sb}$ & $\mathrm{Ta}$ & $\mathrm{Co}$ & $\mathrm{N}$ & \\
\hline 0 & 0.0009 & 0.0109 & 0.007 & 0.0009 & 0.0189 & 0.0096 & \\
\hline
\end{tabular}


EVB 75, from factory Elektrode Jesenice (Slovenia), alloyed basic electrode, in diameters of 2.5 and $3.25 \mathrm{~mm}$, was chosen for the plates welding. The choice was made according to the base material properties and the chosen welding procedure, in this test manual metal arc welding. The chemical composition of electrode EVB 75 is given in Table 2.

Table 2 Chemical composition of filler material (\% wt)

\begin{tabular}{|c|c|c|c|c|c|}
\hline $\mathrm{C}$ & $\mathrm{Si}$ & $\mathrm{Mn}$ & $\mathrm{Cr}$ & $\mathrm{Ni}$ & Mo \\
\hline 0.06 & 0.45 & 1.50 & 0.45 & 2.10 & 0.45 \\
\hline
\end{tabular}

Electrode with diameter of $2.5 \mathrm{~mm}$ was used to fill the root of the $\mathrm{K}$ groove, due to the inaccessibility during welding, while an electrode with $\varnothing 3.25 \mathrm{~mm}$ was used to fill the $\mathrm{K}$ groove. The preheat temperature welding was $170{ }^{\circ} \mathrm{C}$. Specimen of welded joint for mechanical properties of HSLA steel NN-70 (Table 3) are given parallel to the rolling direction.

Table 3 Mechanical properties of welded joint of HSLA steel

\begin{tabular}{|c|c|c|c|c|}
\hline Material & $\begin{array}{c}\text { Yield strength } \\
(\mathrm{MPa})\end{array}$ & $\begin{array}{c}\text { Ultimate strength } \\
(\mathrm{MPa})\end{array}$ & $\begin{array}{c}\text { Elongation } \\
(\%)\end{array}$ & $\begin{array}{c}\text { Contraction } \\
(\%)\end{array}$ \\
\hline $\mathrm{NN}-70$ & 645 & 914 & 22.4 & 66 \\
\hline
\end{tabular}

The specimens used in this experiment are standard Charpy specimens of square cross section, with grinded and polished faces, taken from shielded manual arc butt welded $20 \mathrm{~mm}$ thick plates. Specimen dimensions are: length $\mathrm{L}=55 \mathrm{~mm}$, width $\mathrm{W}=10 \mathrm{~mm}$ and thickness $\mathrm{B}=10 \mathrm{~mm}$, with $2 \mathrm{~mm}$ deep notch, Fig. 4 .

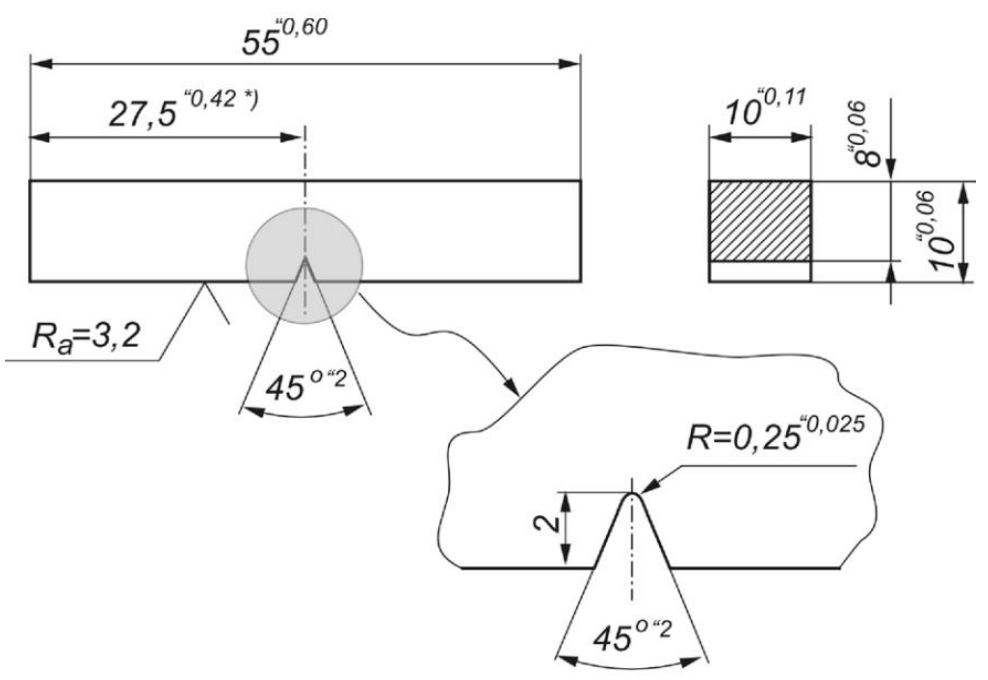

Fig. 4 Charpy specimen for impact energy testing

Impact tests of Charpy specimens with V-notches in parent metal, weld metal and the heat affected zone are performed in order to defined the total impact energy and its two energies - crack initiation and crack propagation energy. In this impact test the focus is on total impact energy. The test method and specimen sizes and shape, as shown in Fig. 4, are defined according to SRPS EN 10045-1 and ASTM E23-02 [11-13]. Impact testing is done on the SCHENCK TREBEL 150-300 J, instrumented Charpy pendulum, at different 
temperatures $\left(20{ }^{\circ} \mathrm{C},-20{ }^{\circ} \mathrm{C},-40{ }^{\circ} \mathrm{C},-60{ }^{\circ} \mathrm{C},-80{ }^{\circ} \mathrm{C}\right.$ and $\left.-100{ }^{\circ} \mathrm{C}\right)$. The position of notch is according to EN 875 [14], Fig. 5. Samples with V-notches were made with perpendicular to rolling direction (11 specimens for parent metal, 9 specimens for weld metal and 9 specimens for heat affected zone where is distance from fusion line $1 \mathrm{~mm}$ ).

Plate (thickness 21mm)
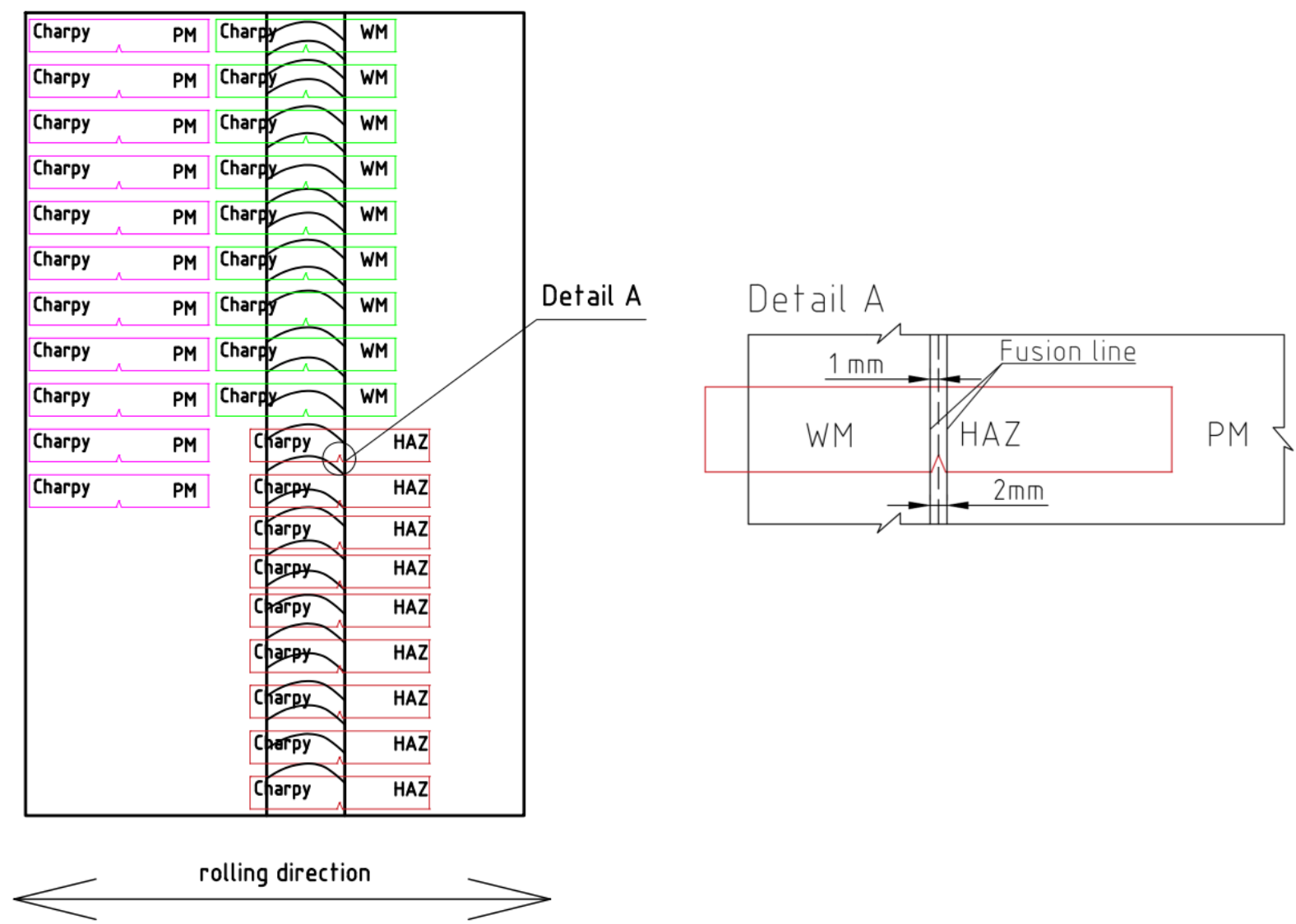

Fig. 5 Notch position of PM, WM and heat affected zone HAZ and detail A with distance from fusion line

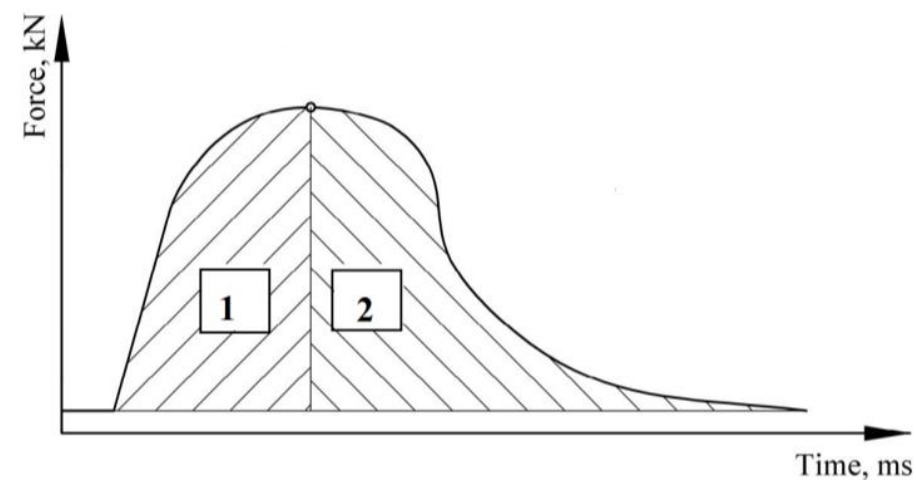

Fig. 6 Typical force-time diagram [4]

By testing the specimen with a notch on the instrumented Charpy pendulum, it is possible to obtain a force-time diagram (Fig. 6). From the considered force-time diagram it is possible to determine the impact total energy required for the specimen fracture using force in function of time and pendulum speed during fracture. The total impact energy is broken down into the part of crack initiation energy and the part of crack propagation energy. Areas 1 and 2 , on the force-time diagram, Fig. 6, are equivalent to crack initiation and propagation energies. Examples of results from total impact energy, crack initiation energy and crack 
propagation energy are given in Table 4 for specimens with notch in parent metal of NN-70, in Table 5 for specimens with notch in weld metal NN-70 and in Table 6 for specimens with notch in heat-affected zone NN-70. More precisely, testing is performed for parent metal at 20 ${ }^{\circ} \mathrm{C}$ ( 3 specimens), $-20{ }^{\circ} \mathrm{C}$ ( 2 specimens $),-60{ }^{\circ} \mathrm{C}$ ( 3 specimens $)$ and $-100{ }^{\circ} \mathrm{C}$ ( 3 specimens $)$. For specimens with notch in weld metal and heat-affected zone, testing is performed at $20{ }^{\circ} \mathrm{C}(3$ specimens for $\mathrm{WM}$ and 3 specimens for $\mathrm{HAZ}),-40{ }^{\circ} \mathrm{C}$ ( 3 specimens for $\mathrm{WM}$ and 3 specimens for HAZ) and $-80{ }^{\circ} \mathrm{C}(3$ specimens for $\mathrm{WM}$ and 3 specimens for HAZ). Also, examples of force-time diagrams for PM, WM and HAZ NN-70 are shown in Fig. 7-9.

Table 4 Impact test results for specimens with notch in parent metal (PM) of NN-70

\begin{tabular}{|c|c|c|c|c|c|c|c|c|c|c|c|}
\hline $\begin{array}{c}\text { Speci- } \\
\text { men }\end{array}$ & $\begin{array}{c}\mathrm{PM} \\
1\end{array}$ & $\begin{array}{c}\mathrm{PM} \\
2\end{array}$ & $\begin{array}{c}\mathrm{PM} \\
3\end{array}$ & $\begin{array}{c}\text { PM } \\
4\end{array}$ & $\begin{array}{c}\mathrm{PM} \\
5\end{array}$ & $\begin{array}{c}\mathrm{PM} \\
6\end{array}$ & $\begin{array}{c}\text { PM } \\
7\end{array}$ & $\begin{array}{c}\mathrm{PM} \\
8\end{array}$ & $\begin{array}{c}\text { PM } \\
9\end{array}$ & $\begin{array}{c}\text { PM } \\
10\end{array}$ & $\begin{array}{c}\text { PM } \\
11\end{array}$ \\
\hline $\begin{array}{l}\text { Test } \\
\text { tempe- } \\
\text { rature } \\
\vartheta\left[{ }^{\circ} \mathrm{C}\right]\end{array}$ & 20 & 20 & 20 & -20 & -20 & -60 & -60 & -60 & -100 & -100 & -100 \\
\hline $\begin{array}{c}\text { Total } \\
\text { impact } \\
\text { energy } \\
\mathrm{KV}[\mathrm{J}]\end{array}$ & 97.08 & 97.63 & 95.59 & 96.89 & 96.52 & 60.78 & 87.87 & 86.77 & 52.91 & 58.26 & 63.66 \\
\hline $\begin{array}{c}\text { Crack } \\
\text { initia- } \\
\text { tion } \\
\text { energy } \\
\mathrm{K}_{\mathrm{N}}[\mathrm{J}]\end{array}$ & 39.17 & 40.26 & 39.37 & 41.59 & 37.89 & 41.44 & 37.02 & 37.29 & 46.21 & 41.04 & 41.63 \\
\hline $\begin{array}{c}\text { Crack } \\
\text { propa- } \\
\text { gation } \\
\text { energy } \\
\mathrm{K}_{\mathrm{p}}[\mathrm{J}] \\
\end{array}$ & 57.90 & 57.37 & 56.42 & 55.30 & 58.64 & 19.34 & 50.86 & 49.48 & 6.7 & 17.22 & 22.03 \\
\hline
\end{tabular}

Table 5 Impact test results for specimens with notch in weld metal (WM) of NN-70

\begin{tabular}{|c|c|c|c|c|c|c|c|c|c|}
\hline Specimen & $\begin{array}{c}\text { WM } \\
1\end{array}$ & $\begin{array}{c}\text { WM } \\
2\end{array}$ & $\begin{array}{c}\text { WM } \\
3\end{array}$ & $\begin{array}{c}\text { WM } \\
4\end{array}$ & $\begin{array}{c}\text { WM } \\
5\end{array}$ & $\begin{array}{c}\text { WM } \\
6\end{array}$ & $\begin{array}{c}\text { WM } \\
7\end{array}$ & $\begin{array}{c}\text { WM } \\
8\end{array}$ & $\begin{array}{c}\text { WM } \\
9\end{array}$ \\
\hline $\begin{array}{c}\text { Test tempera- } \\
\text { ture } \\
\vartheta\left[{ }^{\circ} \mathrm{C}\right]\end{array}$ & 20 & 20 & 20 & -40 & -40 & -40 & -80 & -80 & -80 \\
\hline $\begin{array}{c}\text { Total impact } \\
\text { energy } \\
\mathrm{KV}[\mathrm{J}]\end{array}$ & 78.24 & 79.82 & 86.79 & 53.69 & 34.11 & 53.38 & 18.28 & 22.83 & 20.44 \\
\hline $\begin{array}{c}\text { Crack } \\
\text { initiation } \\
\text { energy } \\
\mathrm{K}_{\mathrm{N}}[\mathrm{J}]\end{array}$ & 24.60 & 24.48 & 28.55 & 21.85 & 19.96 & 20.90 & 0 & 0 & 0 \\
\hline $\begin{array}{c}\text { Crack } \\
\text { propagation } \\
\text { energy } \\
\mathrm{K}_{\mathrm{p}}[\mathrm{J}]\end{array}$ & 53.64 & 55.34 & 58.25 & 31.85 & 14.15 & 32.48 & 18.28 & 22.83 & 20.44 \\
\hline
\end{tabular}


Table 6 Impact test results for specimens with notch in heat-affected zone (HAZ) of NN-70

\begin{tabular}{|c|c|c|c|c|c|c|c|c|c|}
\hline Specimen & HAZ & HAZ & HAZ & HAZ & HAZ & HAZ & HAZ & HAZ & HAZ \\
& 1 & 2 & 3 & 4 & 5 & 6 & 7 & 8 & 9 \\
\hline $\begin{array}{c}\text { Test } \\
\text { tempera- } \\
\text { ture } \\
\vartheta\left[{ }^{\circ} \mathrm{C}\right]\end{array}$ & 20 & 20 & 20 & -40 & -40 & -40 & -80 & -80 & -80 \\
\hline $\begin{array}{c}\text { Total } \\
\text { impact } \\
\text { energy } \\
\text { KV }[\mathrm{J}]\end{array}$ & 104.88 & 109.67 & 120.18 & 98.59 & 106.79 & 108.35 & 51.34 & 87.02 & 13.36 \\
\hline $\begin{array}{c}\text { Crack } \\
\text { initiation } \\
\text { energy } \\
\mathrm{K}_{\mathrm{N}}[\mathrm{J}]\end{array}$ & 26.80 & 28.40 & 34.23 & 32.58 & 33.24 & 35.04 & 27.99 & 27.40 & 0 \\
\hline $\begin{array}{c}\text { Crack } \\
\text { propagation } \\
\text { energy } \\
\mathrm{K}_{\mathrm{p}}[\mathrm{J}]\end{array}$ & 78.09 & 81.27 & 85.95 & 66.01 & 73.55 & 73.31 & 23.35 & 59.62 & 13.36 \\
\hline
\end{tabular}

$20^{\circ} \mathrm{C}$

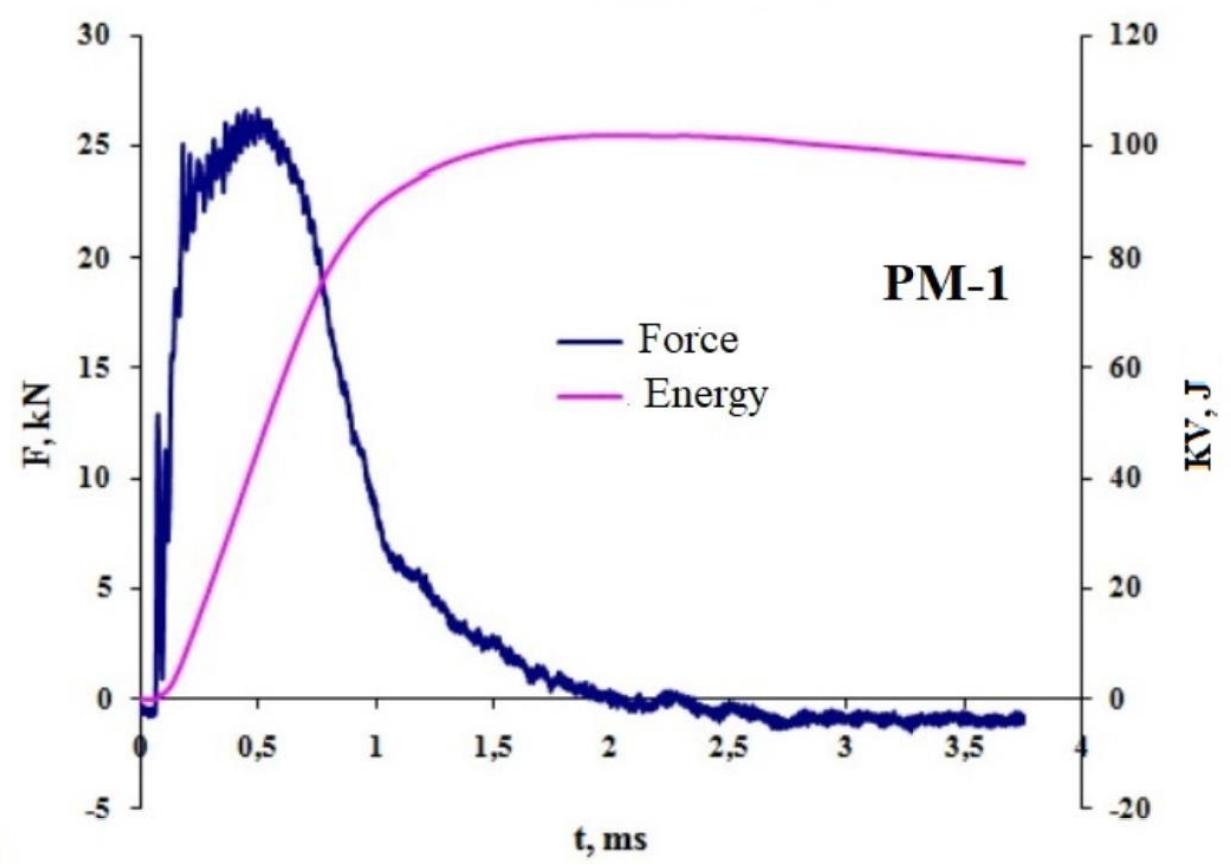

Fig. 7 Diagram obtained by impact testing for parent metal of $\mathrm{NN}-70$ at $20^{\circ} \mathrm{C}$ 


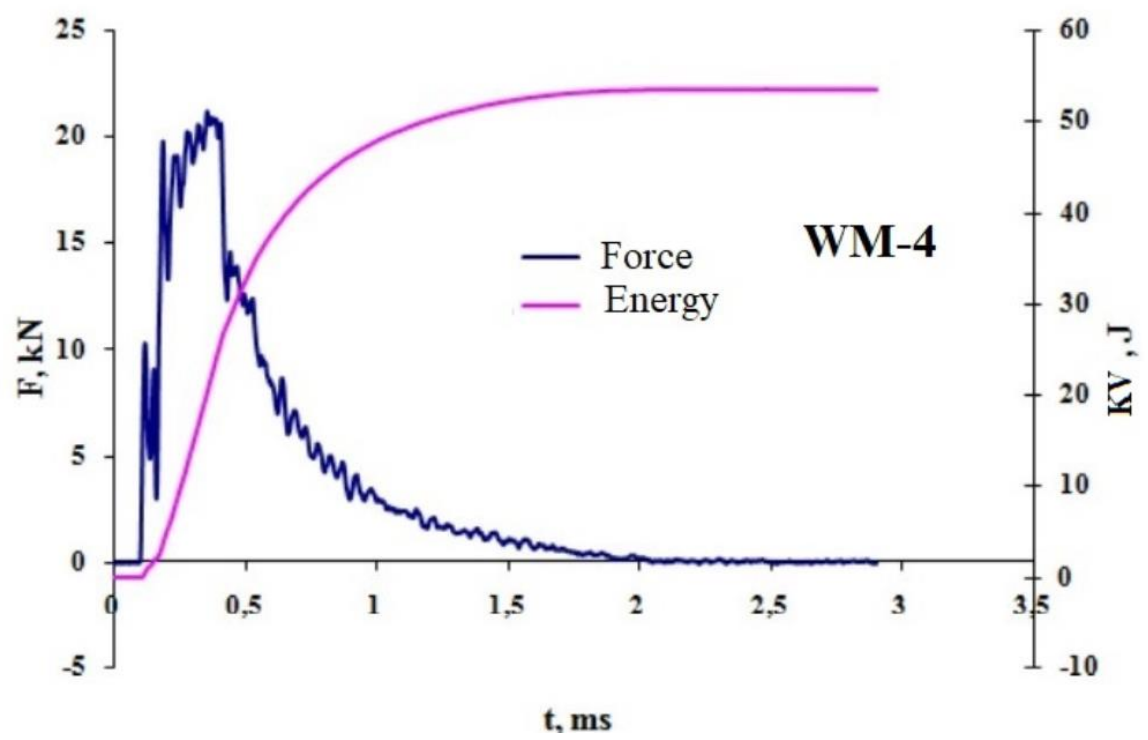

Fig. 8 Diagram obtained by impact testing for weld metal of $\mathrm{NN}-70$ at $-40^{\circ} \mathrm{C}$

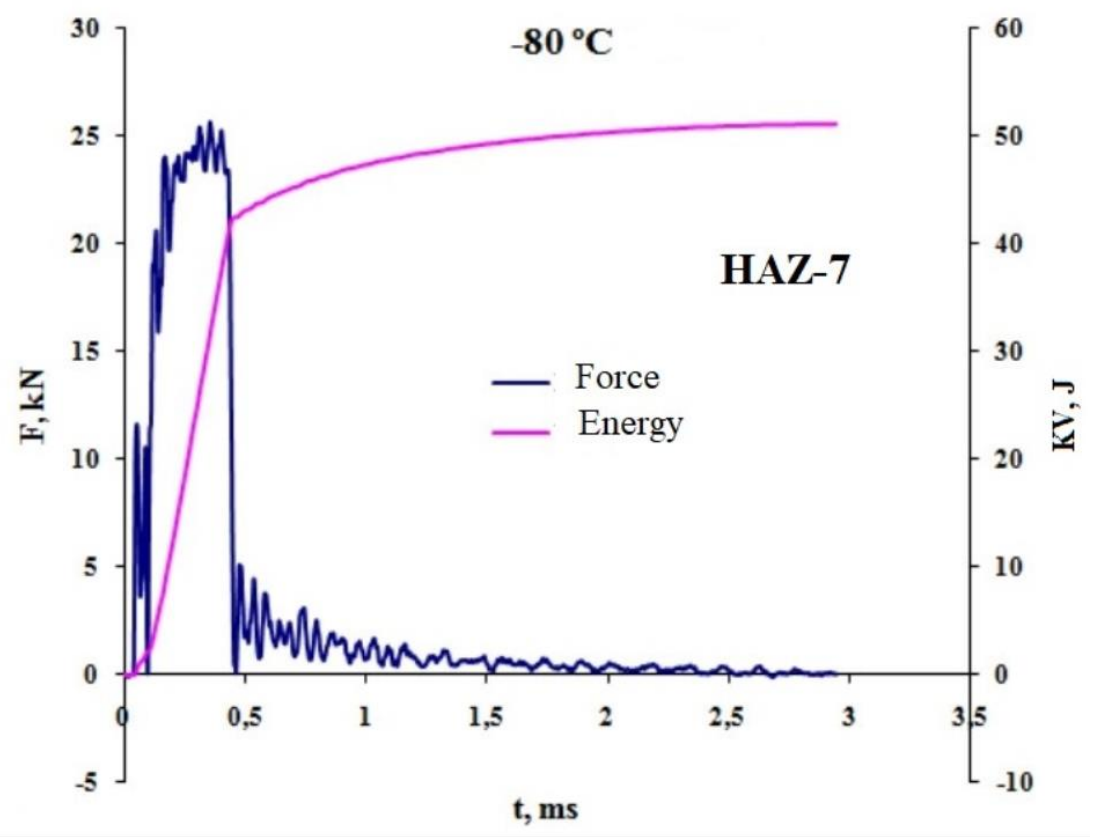

Fig. 9 Diagram obtained by impact testing for heat-affected zone of $\mathrm{NN}-70$ at $-80^{\circ} \mathrm{C}$

Using the values of the total energy, a diagram that refers to the relation between total impact energy and test temperature was formed. This diagram (Fig. 10) is presented in order to determine the ductile-brittle transition temperature as a significant parameter obtained by impact tests at different temperatures. As there are several ways to determine the transition or critical temperature, the criterion $27 \mathrm{~J}$ was used in this experiment. This is the temperature at which the total impact energy is $27 \mathrm{~J}$. It should be mentioned that today this criterion is one of the most common in determining the transition temperature. The transition temperature values for parent metal (PM), weld metal (WM) and heat-affected zone HAZ are shown in the Table 7 below. 


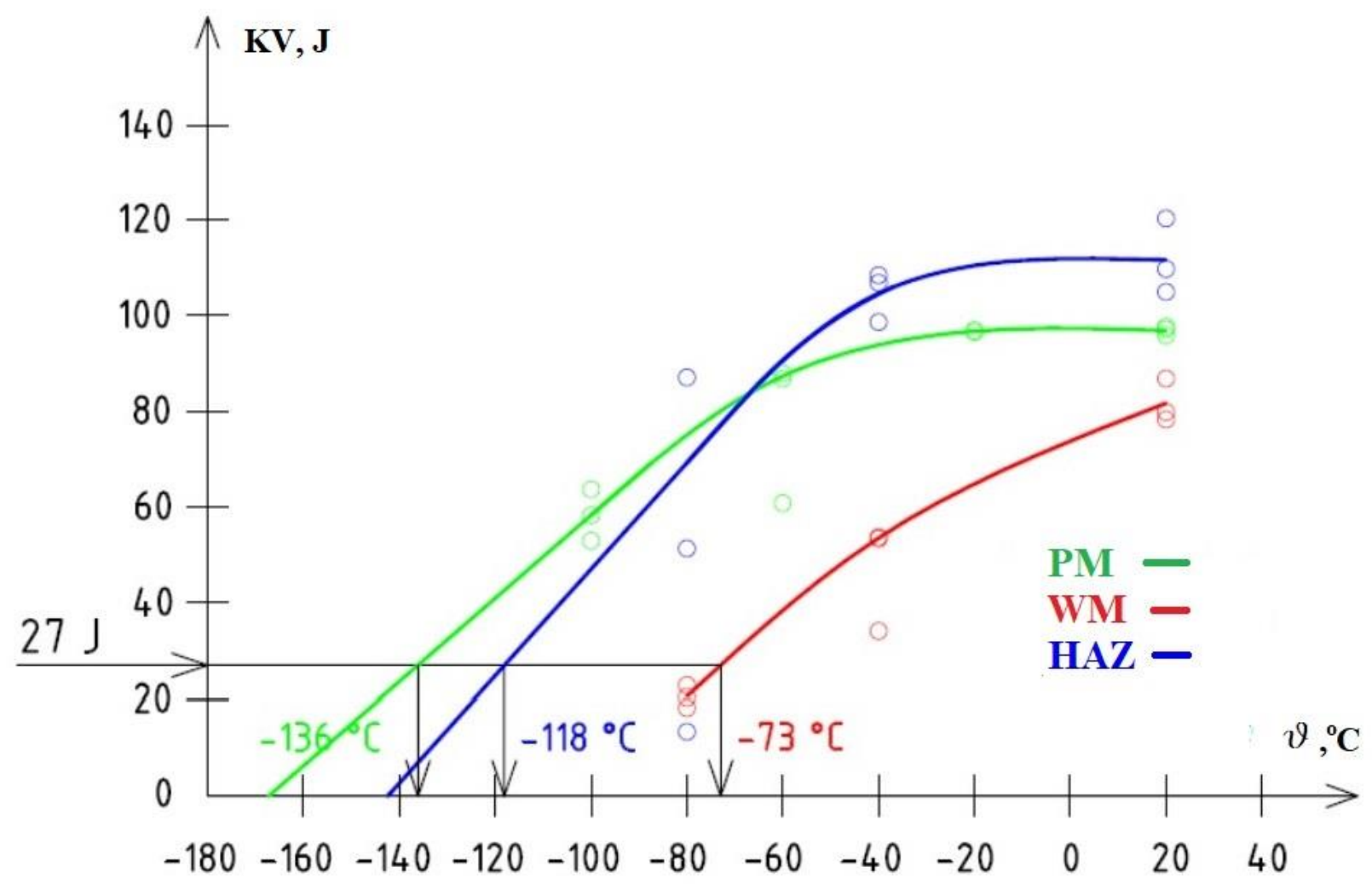

Fig. 10 Notch total impact energy as a function of temperature for PM, WM and HAZ

Table 7 Transition temperature values for PM, WM and HAZ of NN-70

\begin{tabular}{|c|c|}
\hline Notch position & $\begin{array}{c}\text { Transition temperature } \\
{\left[{ }^{\circ} \mathrm{C}\right]}\end{array}$ \\
\hline parent metal (PM) & -136 \\
\hline weld metal (WM) & -73 \\
\hline heat-affected zone (HAZ) & -118 \\
\hline
\end{tabular}

\section{Conclusion}

Comparing the values in Tables 4-6 for all three parts of the welded joint of steel NN70 , it follows that the values of total impact energy and values of crack propagation energy are highest in tests at $20^{\circ} \mathrm{C}$, which means that as the temperature decreases, the toughness of the material decreases. Also, analyzing values in Tables 4-6 it can be concluded that the values for crack initiation energy at different temperatures are highest in parent metal in relation to heat affected zone and weld metal, which can be related to the interpretation with the values of transition temperature. Also, it can be concluded that the values of crack propagation energy are the highest in HAZ.

The location where specimens were taken has an effect on the impact total energy value $\mathrm{KV}$, as well as the $\mathrm{V}$-notch position. Thus, based on the obtained results of impact tests, it can be seen that the total impact energy depends on: the location where specimens were taken (parent metal, weld metal and heat affected zone) and test temperature.

The test results of high strength low-alloy steel toughness assessment at different test temperatures show that temperature significantly affects the impact toughness of steels. At higher temperatures the impact energy on fracture is high (the material shows the properties of plasticity) while at lower temperatures the impact energy is small (the material is brittle). 
The diagram in Fig. 10 shows that the decrease in the test temperature leads to the formation of brittle fracture in the form of a successive decrease in the total impact energy from 20 to $-100{ }^{\circ} \mathrm{C}$ in parent metal and from 20 to $-80{ }^{\circ} \mathrm{C}$ in weld metal and heat affected zone of high strength low-alloy steel Nionikral 70 (NN-70). In general, it can be seen that the highest influence on the value of the total impact energy has the test temperature, because it is closely related to the plastic properties of high strength low-alloy steel.

Based on the values obtained from the diagram in Fig. 10 the transition temperature for parent metal is $-136^{\circ} \mathrm{C}$, for weld metal $-73^{\circ} \mathrm{C}$ and for heat affected zone $-118^{\circ} \mathrm{C}$. It can be concluded that parent metal has the highest resistance to the transition to the brittle state or in other words to the transition from ductile to brittle state.

Behaviour of steels generally used for marine construction is well known, and therefore it's easy to define demands regarding their use for ship hull structures. Selection of structural steels for hull making with adequate toughness at predetermined service temperatures is very important.

\section{Acknowledgement}

This research is supported by the Ministry of Education, Science and Technological Development of the Republic of Serbia (Contract No. 451-03-9/2021-14/ 200012).

\section{REFERENCES}

[1] Aung, H. (2007). An analysis of the study of mechanical properties and microstructural relationship of HSLA steels used in ship hulls. World Maritime University Dissertations.

[2] Yongjin, G., Luyun, C., Hongdong, W., Hong, Y. (2019). Experimental Study of Welding Residual Stress of High-Strength Shipbuilding Steel. Brodogradnja, Vol. 70, no. 2, pp. 17-32. https://doi.org/10.21278/brod70202

[3] Aleksic, V., Milovic, Lj., Blacic, I., Vuherer, T., Bulatovic, S. (2019). Effect of LCF on behavior and microstructure of microalloyed HSLA steel and its simulated CGHAZ. Engineering Failure Analysis, Vol. 104, pp. 1094-1106. https://doi.org/10.1016/j.engfailanal.2019.06.017

[4] Grabulov, V., Blačić, I., Radović, A., Sedmak, S. (2008). Toughness and ductility of high strength steels welded joints. Structural integrity and life, Vol. 8, no. 3, pp. 181-190.

[5] Čamagić, I., Vasić, N., Ćirković, B., Cvetković, S., Vasić, Z. (2010). Variable and impact load testing of HSLA steel welds. Structural integrity and life, Vol. 10, no. 3, pp. 231-234.

[6] Đorđević V. (2000). Ispitivanje udarom. Mašinski materijali-prvi deo. Mašinski fakultet Univerziteta u Beogradu, pp. 99-101.

[7] Popović O, Sedmak A, Trišović N. (2002). Material toughness assessment using different parameters obtained by Charpy pendulum. Structural Integrity and Life, Vol. 2, pp. 29-38.

[8] Board of Investigation (1947). Final Report: the design and methods of construction of welded steel merchant vessels. Washington DC: US Government Printing Office.

[9] Radović, N., Drobnjak, Đ. (2001). Development of steels for fabrication of welded constructions with improved safety. Zavarivanje i zavarene konstrukcije, Vol. 46, no. 3, pp. 81-92.

[10] Das, A., Chowdhury, T., Tarafder, S. (2014). Ductile fracture micro-mechanisms of high strength low alloy steels. Materials and Design, Vol. 54, pp. 1002-1009. https://doi.org/10.1016/j.matdes.2013.09.018

[11] Jovanović, M., Čamagić, I., Sedmak, S.A., Živković. P., Sedmak, A. (2020). Crack initiation and propagation resistance of HSLA steel welded joint constituents. Structural integrity and life, Vol. 20, no. 1, pp. 11-14. 
[12] SRPS EN 10045-1:1993. (1993). Mehanička ispitivanja metala - ispitivanje udarom po Šarpiju, Deo 1: Metoda ispitivanja.

[13] ASTM E 23-02. (2002). Standard Test Methods for Notched Bar Impact Testing of Metallic Materials, Annual Book of ASTM Standards, Vol. 03.01.

[14] EN 875 (1995). Destructive tests on welds in metallic materials - Impact tests - Test specimen location, notch orientation and examination. Comite Europeen de Normalisation.

Submitted: $\quad$ 22.06.2021. Srđan Bulatović, srdjan.bulatovic@institutims.rs

Accepted: 13.08.2021 Institute for Materials Testing-IMS, Bulevar vojvode Mišića 43, Belgrade,

Aujadin Aleksić, vujadin.aleksic@institutims.rs

Institute for Materials Testing-IMS, Bulevar vojvode Mišića 43, Belgrade,

Serbia

Ljubica Milović, acibulj@tmf.bg.ac.rs

University of Belgrade, Faculty of Technology and Metallurgy, Karnegijeva

4, Belgrade, Serbia

Bojana Zečević, baleksic@tmf.bg.ac.rs,

University of Belgrade, Innovation Centre of Faculty of Technology and

Metallurgy, Karnegijeva 4, Belgrade, Serbia 